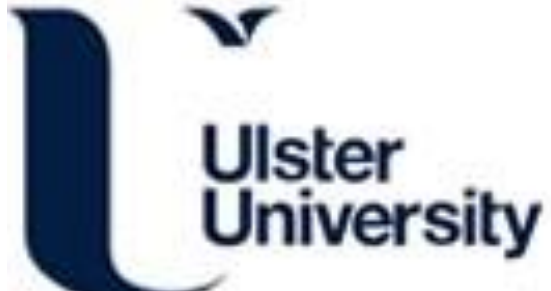

\section{Synthesis and characterisation of nanophase hydroxyapatite co-substitutedwith strontium and zinc}

Lowry, N., Brolly, M., Han, Y., McKillop, S., Meenan, B., \& Boyd, A. (2018). Synthesis and characterisation of nanophase hydroxyapatite co-substitutedwith strontium and zinc. Ceramics International, 44(7), 7761-7770. https://doi.org/10.1016/j.ceramint.2018.01.206

Link to publication record in Ulster University Research Portal

\section{Published in:}

Ceramics International

Publication Status:

Published (in print/issue): 31/05/2018

DOI:

10.1016/j.ceramint.2018.01.206

\section{Document Version}

Author Accepted version

\section{General rights}

Copyright for the publications made accessible via Ulster University's Research Portal is retained by the author(s) and / or other copyright owners and it is a condition of accessing these publications that users recognise and abide by the legal requirements associated with these rights.

\section{Take down policy}

The Research Portal is Ulster University's institutional repository that provides access to Ulster's research outputs. Every effort has been made to ensure that content in the Research Portal does not infringe any person's rights, or applicable UK laws. If you discover content in the Research Portal that you believe breaches copyright or violates any law, please contact pure-support@ulster.ac.uk. 


\title{
Synthesis and characterisation of nanophase hydroxyapatite co-substituted with strontium and zinc
}

\author{
N. Lowry*, M. Brolly, Y. Han, S. McKillop, B.J. Meenan, A.R. Boyd \\ Nanotechnology and Integrated Bioengineering Centre (NIBEC), School of Engineering, Ulster University, Northern Ireland, UK
}

\section{A R T I C L E I N F O}

\section{Keywords:}

Bioceramic

Nano-hydroxyapatite

Co-substitution

Strontium

Zinc

\begin{abstract}
A B S T R A C T
In order to develop new bioactive calcium phosphate (CaP) materials to repair bone defects, it is important to ensure these materials more closely mimic the non-stoichiometric nature of biological hydroxyapatite (HA). Typically, biological HA combines various $\mathrm{CaP}$ phases with different impurity ions, which substitute within the HA lattice, including strontium $\left(\mathrm{Sr}^{2+}\right)$, zinc $\left(\mathrm{Zn}^{2+}\right)$, magnesium $\left(\mathrm{Mg}^{2+}\right)$, carbonate $\left(\mathrm{CO}_{3}{ }^{2-}\right)$ and fluoride $\left(\mathrm{F}^{-}\right)$, but to name a few. In addition to this biological HA have dimensions in the nanometre (nm) range, usually $60 \mathrm{~nm}$ in length by $5-20 \mathrm{~nm}$ wide. Both the effects of ion substitution and the nano-size crystals are seen as important factors for enhancing their potential biofunctionality. The driving hypothesis was to successfully synthesise nanoscale hydroxyapatite (nHA), co-substituted with strontium $\left(\mathrm{Sr}^{2+}\right)$ and zinc $\left(\mathrm{Zn}^{2+}\right)$ ions in varying concentrations using an aqueous precipitation method and to understand their chemical and physical properties. The materials were characterised using Fourier Transform Infrared Spectroscopy (FTIR), X-Ray Diffraction (XRD), X-Ray Photoelectron Spectroscopy (XPS) and Transmission Electron Microscopy (TEM) techniques. The FTIR, XRD and XPS results confirmed that the nHA was successfully co-substituted with $\mathrm{Sr}^{2+}$ and $\mathrm{Zn}^{2+}, \mathrm{re}^{-}$ placing $\mathrm{Ca}^{2+}$ within the nHA lattice at varying concentrations. The FTIR results confirmed that all of the samples were carbonated, with a significant loss of hydroxylation as a consequence of the incorporation of $\mathrm{Sr}^{2+}$ and $\mathrm{Zn}^{2+}$ into the nHA lattice. The TEM results showed that each sample produced was nano-sized, with the $\mathrm{Sr} / \mathrm{Zn}-10 \%$ nHA having the smallest sized crystals approximately $17.6 \pm 3.3 \mathrm{~nm}$ long and $10.2 \pm 1.4 \mathrm{~nm}$ wide. None of the materials synthesised here in this study contained any other impurity CaP phases. Therefore, this study has shown that co-substituted nHA can be prepared, and that the degree of substitution (and the substituting ion) can have a profound effect on the attendant materials' properties.
\end{abstract}

\section{Introduction}

Synthetic hydroxyapatite (HA) $\left[\mathrm{Ca}_{10}\left(\mathrm{PO}_{4}\right)_{6}(\mathrm{OH})_{2}\right]$ has been used extensively as a bone augmentation biomaterial, producing scaffolds for bone tissue engineering and for coating implants to promote bone healing and more effectively enhancing osseointegration $[1,2]$. It is well understood that nanoscale hydroxyapatite (nHA) with an average particle size of less than $20 \mathrm{~nm}$ can optimise the biofunctionality and bioactivity of HA, by increasing osteoblast cell proliferation [2].

Typically, biological apatite is non-stoichiometric and incorporates various impurity ions within the HA crystal lattice, Table 1 summarises the numerous substitutions which can occur, of those listed strontium and zinc have been shown to add significant enhancements to the properties of the HA individually. However, it has been suggested that co-substitutes of strontium and zinc could deliver a range of significant benefits over single ion substitutes $[3,4]$. Strontium and zinc co- substituted within the nHA lattice can optimise osteoconductivity by assisting new bone growth and improve osteoinductivity, by encouraging the differentiation of mesenchymal stem cells to osteoblasts, which could work effectively to prevent osteoporosis [5-7]. Both ions have also been found to produce an antimicrobial response and zinc in particular may inhibit the growth of Streptococcus mutans, Staphylococcus aureus, Escherichia coli and Candida albicans [8,9]. Therefore, both ions co-substituted together may also provide an effective antimicrobial treatment to combat conditions such as osteomyelitis [8].

The driving hypothesis of this work was to successfully synthesise nHA in a stoichiometric form, along with nHA co-substituted with $\mathrm{Sr}^{2+}$ and $\mathrm{Zn}^{2+}$ ions at a range of different weight percentage(wt\%) concentrations, Sr/Zn-2.5\%nHA, Sr/Zn-5\%nHA and Sr/Zn-10\%nHA. From previous research, one would expect the crystallinity, particle morphology and phase purity to vary as the level of ionic co-substitution was increased from $2.5 \%$ to $5-10 \% \mathrm{Sr} / \mathrm{Zn}[10,11]$. Each sample was

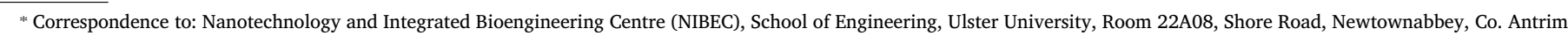
BT37 OQB, Northern Ireland, UK.

E-mail address: lowry-n2@ulster.ac.uk (N. Lowry). 


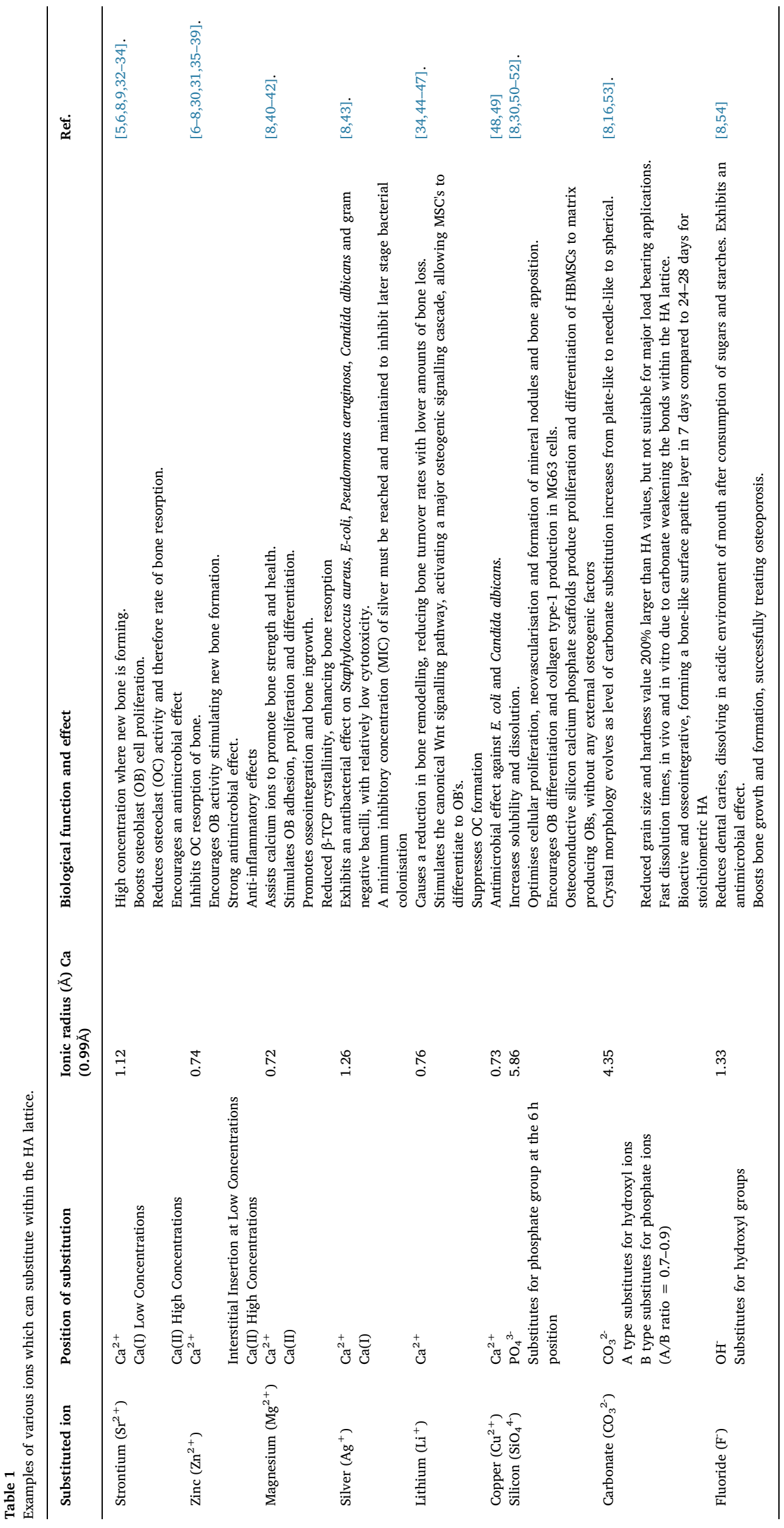


Table 2

Nomenclature used to describe samples for the study.

\begin{tabular}{|c|c|c|c|c|c|c|c|}
\hline \multirow[t]{2}{*}{ Sample name } & \multirow{2}{*}{$\begin{array}{l}\text { Abbreviation } \\
\text { used }\end{array}$} & \multirow[t]{2}{*}{ Chemical formula } & \multicolumn{5}{|c|}{ Molar quantity (mmol) } \\
\hline & & & $\mathrm{Ca}\left(\mathrm{OH}_{2}\right)$ & $\mathrm{H}_{3} \mathrm{PO}_{4}$ & $\mathrm{Ca}\left(\mathrm{NO}_{3}\right)_{2} \cdot 4 \mathrm{H}_{2} \mathrm{O}$ & $\mathrm{Sr}\left(\mathrm{NO}_{3}\right)_{2} \cdot 4 \mathrm{H}_{2} \mathrm{O}$ & $\begin{array}{l}\mathrm{Zn}\left(\mathrm{NO}_{3}\right)_{2} \\
\mathrm{H}_{2} \mathrm{O}\end{array}$ \\
\hline Synthesised Nanoscale Hydroxyapatite & nHA & $\mathrm{Ca}_{10}\left(\mathrm{PO}_{4}\right)_{6}(\mathrm{OH})_{2}$ & 50.000 & 29.900 & - & - & - \\
\hline $\begin{array}{l}\text { Synthesised Nanoscale Sr/Zn co- substituted } \\
\text { Hydroxyapatite }(1.25 \% / 1.25 \%)\end{array}$ & $\mathrm{Sr} / \mathrm{Zn}-2.5 \% \mathrm{nHA}$ & $\mathrm{Ca}_{9.75} \mathrm{Sr}_{0.125} \mathrm{Zn}_{0.125}\left(\mathrm{PO}_{4}\right)_{6}(\mathrm{OH})_{2}$ & - & 29.900 & 48.750 & 0.625 & 0.625 \\
\hline $\begin{array}{l}\text { Synthesised Nanoscale Sr/Zn co- substituted } \\
\text { Hydroxyapatite }(2.5 \% / 2.5 \%)\end{array}$ & $\mathrm{Sr} / \mathrm{Zn}-5 \% \mathrm{nHA}$ & $\mathrm{Ca}_{9.5} \mathrm{Sr}_{0.25} \mathrm{Zn}_{0.25}\left(\mathrm{PO}_{4}\right)_{6}(\mathrm{OH})_{2}$ & - & 29.900 & 47.500 & 1.250 & 1.250 \\
\hline $\begin{array}{l}\text { Synthesised Nanoscale } \mathrm{Sr} / \mathrm{Zn} \text { co- substituted } \\
\text { Hydroxyapatite }(5 \% / 5 \%)\end{array}$ & $\mathrm{Sr} / \mathrm{Zn}-10 \% \mathrm{nHA}$ & $\mathrm{Ca}_{9} \mathrm{Sr}_{0.5} \mathrm{Zn}_{0.5}\left(\mathrm{PO}_{4}\right)_{6}(\mathrm{OH})_{2}$ & - & 29.900 & 45.000 & 2.500 & 2.500 \\
\hline
\end{tabular}

characterised and compared to the stoichiometric nHA using X-ray Diffraction (XRD), Fourier Transform Infrared Spectroscopy (FTIR), Xray Photoelectron Spectroscopy (XPS) and Transmission Electron Microscopy (TEM). To the best of our knowledge, this paper represents one of the first attempts to produce, systematically characterise and compare the physicochemical properties of nano-hydroxyapatite, cosubstituted to these various $\mathrm{Sr}^{2+} / \mathrm{Zn}^{2+}$ combined weight percentages, produced under identical conditions of $\mathrm{pH}$ and temperature.

\section{Materials and methods}

The nomenclature used to describe each of the calcium phosphate (CaP) powders synthesised in this study (using a standard aqueous precipitation method) are outlined in Table 2. Identical experimental conditions of temperature $\left(60^{\circ} \mathrm{C}\right)$ and $\mathrm{pH} \geq 9$, were used to synthesise pure nanoscale hydroxyapatite (nHA), nanoscale $\operatorname{Sr}(1.25 \%) / \mathrm{Zn}(1.25 \%)$ hydroxyapatite ( $\mathrm{Sr} / \mathrm{Zn}-2.5 \% \mathrm{nHA})$, nanoscale $\operatorname{Sr}(2.5 \%) / \mathrm{Zn}(2.5 \%)$ hydroxyapatite (Sr/Zn-5\%nHA) and nanoscale $\operatorname{Sr}(5 \%) / \mathrm{Zn}(5 \%)$ hydroxyapatite ( $\mathrm{Sr} / \mathrm{Zn}-10 \% \mathrm{nHA})$. Sodium hydroxide was used as a buffer to raise the $\mathrm{pH} \geq 9$ for the co-substitutions, $\mathrm{Sr} / \mathrm{Zn}-2.5 \% \mathrm{nHA}, \mathrm{Sr} / \mathrm{Zn}-5 \%$ nHA and $\mathrm{Sr} / \mathrm{Zn}-10 \%$ nHA. The experimental ratios of $\mathrm{Ca} / \mathrm{P}$ and $(\mathrm{Ca}+$ $\mathrm{M}) / \mathrm{P}$, (where $\mathrm{M}=\mathrm{Sr}$ or $\mathrm{Zn}$ ) were maintained at 1.67 , for final comparison.

\subsection{Aqueous precipitation synthesis of $n H A$}

nHA powders were synthesised using an acid-base reaction of calcium hydroxide $\left(\mathrm{Ca}(\mathrm{OH})_{2}\right.$ - Sigma Aldrich) and phosphoric acid (85 wt $\% \mathrm{H}_{3} \mathrm{PO}_{4}$ - Sigma Aldrich). $\mathrm{Ca}(\mathrm{OH})_{2}$ was suspended in $500 \mathrm{ml}$ of deionised $\mathrm{H}_{2} \mathrm{O}$, heated to $60{ }^{\circ} \mathrm{C}$ and stirred at $400 \mathrm{rpm}$ for $1 \mathrm{~h}$. An aqueous solution of $\mathrm{H}_{3} \mathrm{PO}_{4}$ was prepared by dissolving $85 \mathrm{wt} \% \mathrm{H}_{3} \mathrm{PO}_{4}$ in $500 \mathrm{ml}$ of deionised $\mathrm{H}_{2} \mathrm{O}$. The $\mathrm{H}_{3} \mathrm{PO}_{4}$ solution was added to the $\mathrm{Ca}$ $\left(\mathrm{OH}_{2}\right)$ solution at a rate of $3.5 \mathrm{ml} / \mathrm{min}$ using a peristalic pump. The solution was stirred for a further $2 \mathrm{~h}$ and allowed to settle and cool overnight. The $\mathrm{pH}$ of the solution was measured at 9.1. The precipitate was washed 3 times using deionised $\mathrm{H}_{2} \mathrm{O}$ and then dried at $60{ }^{\circ} \mathrm{C}$ in an oven for $24 \mathrm{~h}$.

\subsection{Aqueous precipitation synthesis of strontium and zinc co-substituted $n H A$}

Starting suspensions were prepared by dissolving calcium nitrate tetrahydrate $\left(\mathrm{Ca}\left(\mathrm{NO}_{3}\right)_{4} \cdot 4 \mathrm{H}_{2} \mathrm{O}\right.$ - puriss.pa Sigma Aldrich) with both strontium nitrate $\left(\mathrm{Sr}\left(\mathrm{NO}_{3}\right)_{2} \cdot 4 \mathrm{H}_{2} \mathrm{O}\right.$ - puriss pa. Sigma Aldrich) and zinc nitrate hexahydrate $\left(\mathrm{Zn}\left(\mathrm{NO}_{3}\right)_{2} \cdot \mathrm{H}_{2} \mathrm{O}\right.$ - Sigma Aldrich) in $500 \mathrm{ml}$ of deionised $\mathrm{H}_{2} \mathrm{O}$. The solution was stirred for $1 \mathrm{~h}$ at $60^{\circ} \mathrm{C}$ and $400 \mathrm{rpm}$. An aqueous solution of $\mathrm{H}_{3} \mathrm{PO}_{4}$ was prepared by dissolving $85 \mathrm{wt} \%$ $\mathrm{H}_{3} \mathrm{PO}_{4}$ in $500 \mathrm{ml}$ of deionised $\mathrm{H}_{2} \mathrm{O}$. The $\mathrm{H}_{3} \mathrm{PO}_{4}$ solution was added to the $\mathrm{Ca}\left(\mathrm{NO}_{3}\right)_{2} \cdot 4 \mathrm{H}_{2} \mathrm{O}$ solution at a rate of $3.5 \mathrm{ml} / \mathrm{min}$ using a peristalic pump. The pH of each solution was typically measured between 2.0 and 2.5 , with the solutions remaining colourless. On addition of the sodium hydroxide to buffer each co-substituted solution to a $\mathrm{pH} \geq 10$, a white precipitate formed immediately. The solution was stirred for a further $2 \mathrm{~h}$, with the $\mathrm{pH}$ maintained at $\geq 10$ (by further addition of sodium hydroxide). The solution was allowed to settle and cool to room temperature overnight. The formed precipitate was washed 3 times using deionised $\mathrm{H}_{2} \mathrm{O}$ and then dried at $60^{\circ} \mathrm{C}$ in an oven for $24 \mathrm{~h}$.

\subsection{Characterisation of the $n H A$ and co-substituted Sr/Zn-nHA powders}

X-ray Diffraction (XRD) of the samples was carried out using a Bruker D8 Discover Diffractometer fitted with a Gobel mirror. Diffraction scans were obtained using a $\mathrm{Cu} K \alpha \mathrm{X}$-ray radiation $(\lambda=$ $1.540 \AA$ ) source, with a tube voltage of $40 \mathrm{kV}$ and tube current of $40 \mathrm{~mA}$. Each diffraction scan was recorded at $2 \theta$ values from $5^{\circ}$ to $70^{\circ}$, in $0.04^{\circ}$ stepped increments, with a scan dwell time of $10 \mathrm{~s}$ for each increment.

Fourier Transform Infrared (FTIR) spectroscopy scans were obtained for each sample using a BIORAD FTS 3000MX Excalibur series instrument with a PIKE Diffuse Reflectance Infrared Fourier Transform Spectroscopy (DRIFTS) accessory. Samples were studied in absorbance mode from 4000 to $400 \mathrm{~cm}^{-1}$, at a resolution of $4 \mathrm{~cm}^{-1}$, with 20 scans per sample.

X-ray Photoelectron Spectroscopy (XPS) was performed using a Kratos Axis Ultra DLD Spectrometer. Spectra were analysed using monochromated Al Ka X-rays (hr $=1486.6 \mathrm{eV}(\mathrm{eV})$ ) operating at $10 \mathrm{kV}$ and $15 \mathrm{~mA}(150 \mathrm{~W})$. During analysis, a hybrid lens mode was used (electrostatic and magnetic) with a $300 \mu \mathrm{m} \times 700 \mu \mathrm{m}$ analysis area. Wide energy survey scans (WESS) were taken at a pass energy of $160 \mathrm{eV}$, with high resolution spectra recorded at a pass energy of $20 \mathrm{eV}$. A Kratos charge neutraliser system with a filament current of $1.95 \mathrm{~A}$ and a charge balance between $3.3 .3 \mathrm{~V}$ and $3.6 \mathrm{~V}$, was used for all samples. Sample charging effects on the calculated BE positions were adjusted by setting the lowest BE component of the C1s spectral envelope to $285.0 \mathrm{eV}$, which is the generally accepted value for adventitious carbon surface contamination [12]. In total 3 areas were analysed upon each sample and a linear background was subtracted from each XPS spectra. The peak area of the most intense spectral lines for each elemental species was used to determine the percentage atomic concentration.

Transmission Electron Microscopy (TEM) observations were carried out using a JEOL $2100 \mathrm{f}$ microscope operated at $200 \mathrm{kV}$. Bright-field images were recorded from the powders supported on carbon films for size analysis. ImageJ software was utilised to measure the dimensions of 30 nanocrystals from each sample across 6 different TEM images. The results are reported as the mean \pm standard deviation.

\subsection{Statistical analysis}

The statistical analysis for the TEM data was performed with GraphPad Prism version 5.00 for Windows, GraphPad Software, San Diego California USA. One way analysis of variance (ANOVA) was used 


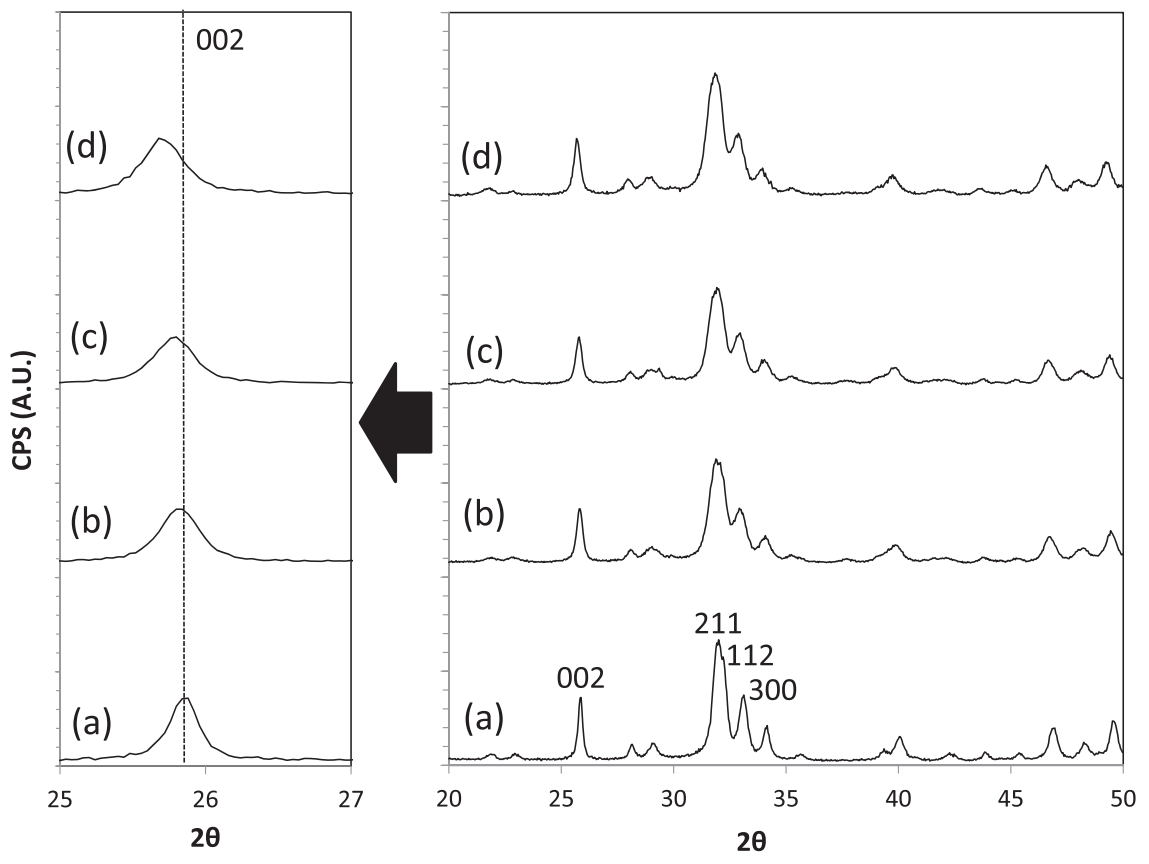

Fig. 1. XRD scans for nHA and co-substituted nHA samples.

to compare mean values in order to determine equivalence of variance between pairs of samples. Significance between groups was determined using the Bonferroni multiple comparison test. A value of $\mathrm{P}<.05$ was taken as statistically significant.

\section{Results}

\section{1. $X R D$}

The comparative XRD patterns for the nHA, Sr/Zn2.5\%nHA, Sr/ Zn5\%nHA and Sr/Zn10\%nHA are shown in Fig. 1(a)-(d). The diffraction pattern for the nHA material is given in Fig. 1(a) and closely correlates to the International Centre for Diffraction Data (ICDD) file \# 0009-0432 for hydroxyapatite (HA). The peak positions and intensities recorded clearly indicate that the nHA material contains no detectable impurity phases. Fig. 1(b)-(d) for the Sr/Zn2.5\%nHA, Sr/Zn5\%nHA and $\mathrm{Sr} / \mathrm{Zn} 10 \%$ nHA samples, respectively, show diffraction peaks that are poorly resolved, indicating that each of the synthesised materials are nanoscale ( $\leq 100 \mathrm{~nm}$ ), and/or have appreciable levels of substitutions within the nHA lattice, whereby $\mathrm{Sr}^{2+}$ and $\mathrm{Zn}^{2+}$ are substituting for $\mathrm{Ca}^{2+}$. All 3 substituted nHA samples, $\mathrm{Sr} / \mathrm{Zn} 2.5 \% \mathrm{nHA}, \mathrm{Sr} /$ Zn5\%nHA and Sr/Zn10\%nHA exhibit noticeable shifts in XRD peak positions to lesser $2 \theta$ values, causing individual peak movement to the left, this is highlighted in Fig. 1 with movement of the 002 peak highlighted.

\subsection{FTIR}

FTIR spectra of the synthesised nHA and substituted nHA powders are shown in Fig. 2(a)-(d), respectively. Typical P-O stretching vibrations are clearly seen between 1200 and $900 \mathrm{~cm}^{-1}$, while O-P-O bending vibrations can be observed between 610 and $400 \mathrm{~cm}^{-1}$ for each of the different materials [13]. O-H stretching and librational bands are also clearly visible around $3570 \mathrm{~cm}^{-1}$ and $632 \mathrm{~cm}^{-1}$, respectively $[14,15]$. In addition to these vibrational bands, carbonate peaks $\left(\mathrm{CO}_{3}{ }^{2-}\right)$ can also be observed between 1550 and $1400 \mathrm{~cm}^{-1}$ and around $870 \mathrm{~cm}^{-1}$ [16]. The carbonate peak positions may indicate that these different materials (both $\mathrm{nHA}$ and substituted $\mathrm{nHA}$ ) have $\mathrm{CO}_{3}{ }^{2-}$ ion substitutions at both the $\mathrm{OH}^{-}$(A-site) and $\mathrm{PO}_{4}{ }^{3-}$ (B-site) positions [13].

\subsection{XPS}

Figs. 3-6 show typical XPS wide energy survey scans (WESS) and high resolution scans recorded as B.E. (e.V.) versus intensity (counts), respectively, for the nHA, Sr/Zn-2.5\%nHA, Sr/Zn-5\%nHA and Sr/ Zn10\%nHA powders (namely the Ca2p, P2s, Sr3p and Zn2p peaks for each sample). Tables 3 and 4 quantify the XPS results recorded here. The main peaks recorded for the nHA sample were Ca2 $\mathrm{p}_{3 / 2}(347.2 \mathrm{eV})$, P2p (133.7 eV), P2s (190.9 eV), and O1s (531.6 eV) are all clearly evident. The peak positions are as expected from previous reports, however, the $\mathrm{Ca} / \mathrm{P}$ ratio was slightly lower than the expected 1.67 for stoichiometric $\mathrm{HA}$, at $1.61 \pm 0.04$ as highlighted in Table 3 $[13,15,17,18]$. For all 3 substituted samples, the $\mathrm{Ca} / \mathrm{P}$ ratios were calculated at $1.53 \pm 0.06$ for $\mathrm{Sr} / \mathrm{Zn}-2.5 \% \mathrm{nHA}, 1.42 \pm 0.03$ for $\mathrm{Sr} / \mathrm{Zn}-5 \%$ nHA and $1.38 \pm 0.01$ for $\mathrm{Sr} / \mathrm{Zn}-10 \%$ nHA, all of which are lower than 1.67 for stoichiometric HA. However, this is as expected and would be a consequence of the substitution of strontium and zinc for calcium within the nHA lattice [19-21].

As all 3 co-substituted samples contain strontium, it should be noted that the spectral envelope observed around $133.5 \mathrm{eV}$ comprises an overlap of the $S r 3 d$ and P2 $p$ peaks as the $S r 3 d_{5 / 2}(133 \pm 0.5 \mathrm{eV}), \mathrm{Sr} 3 d_{3 /}$ ${ }_{2}(135 \pm 0.5 \mathrm{eV})$ and the $\mathrm{P} 2 p(132-133 \mathrm{eV})$ lines are positioned very close together. Therefore, to quantify the phosphorus and strontium atomic concentration \% values in this study for all 3 co-substituted samples, the P2s and Sr3p peaks are used instead of the P2p and Sr3d peaks. The main peaks recorded for all 3 co-substituted samples, shown in Table 4 were therefore $\mathrm{Ca}_{2} \mathrm{p}_{3 / 2} \quad(346.5-347.0 \mathrm{eV}), \quad \mathrm{P} 2 \mathrm{~s}$ (190.0-190.3 eV), O1s (530.5-531.0 eV), Sr3p $\mathrm{p}_{3 / 2}(268.3-268.8 \mathrm{eV})$,

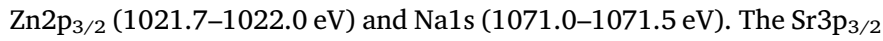
peaks confirm the presence and successful substitution of strontium for

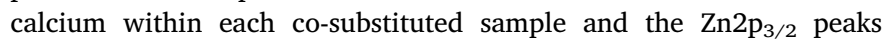
confirm the presence and successful substitution of zinc for calcium within each co-substituted sample.

\subsection{TEM}

The TEM images shown in Fig. 7 confirm that the nHA, Sr/Zn-2.5\% nHA, Sr/Zn-5\%nHA and Sr/Zn-10\%nHA samples produced were all on the nanoscale, with the nHA crystals measuring $99.5 \pm 12.9 \mathrm{~nm}$ in length and $33.8 \pm 7.8 \mathrm{~nm}$ in breadth, with an aspect ratio of 

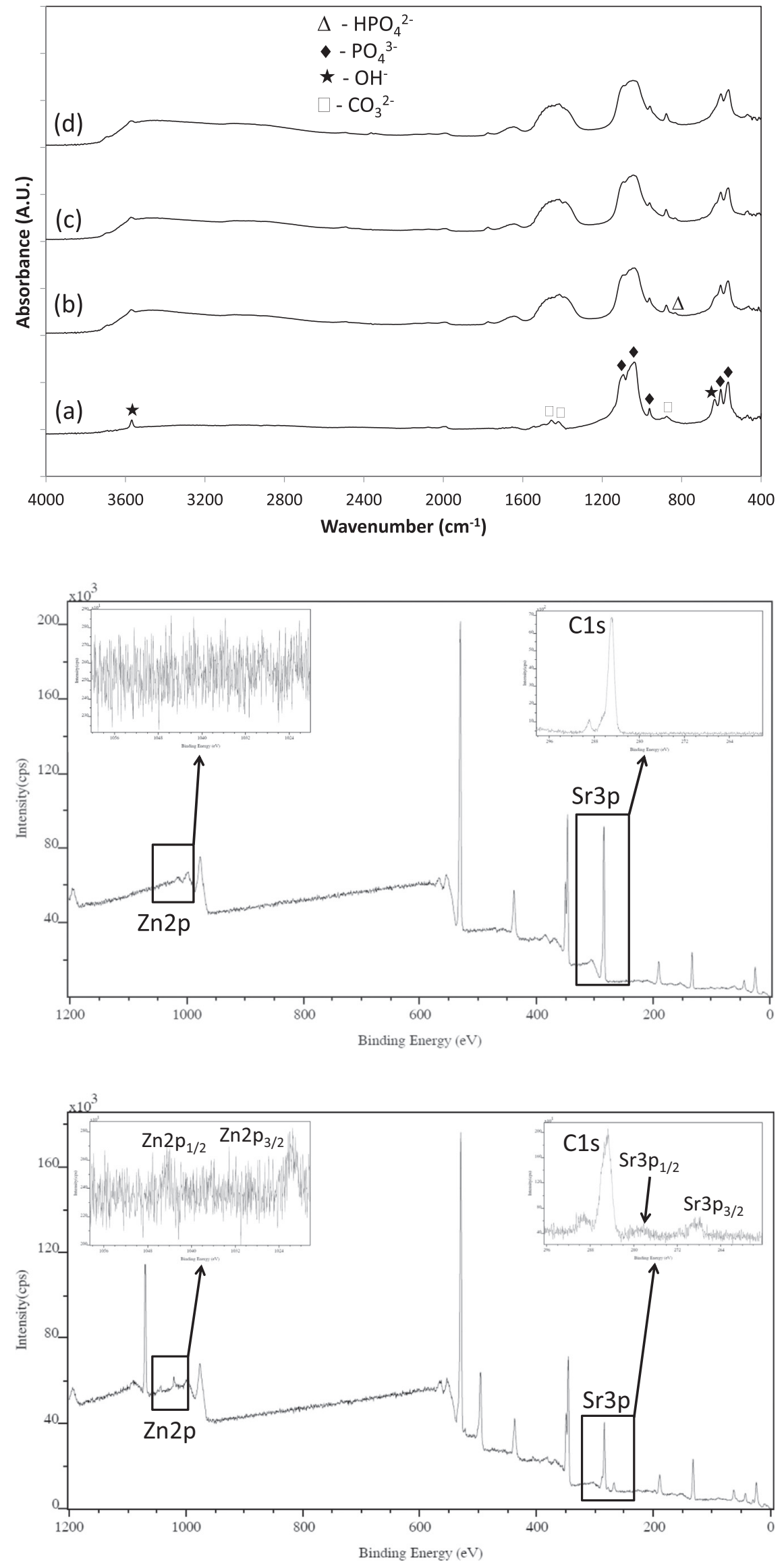

Fig. 2. FTIR spectra for nHA and co-substituted nHA samples.

Fig. 3. XPS spectra for nHA sample.

Fig. 4. XPS spectra for $\mathrm{Sr} / \mathrm{Zn} 2.5 \%$ nHA sample. 

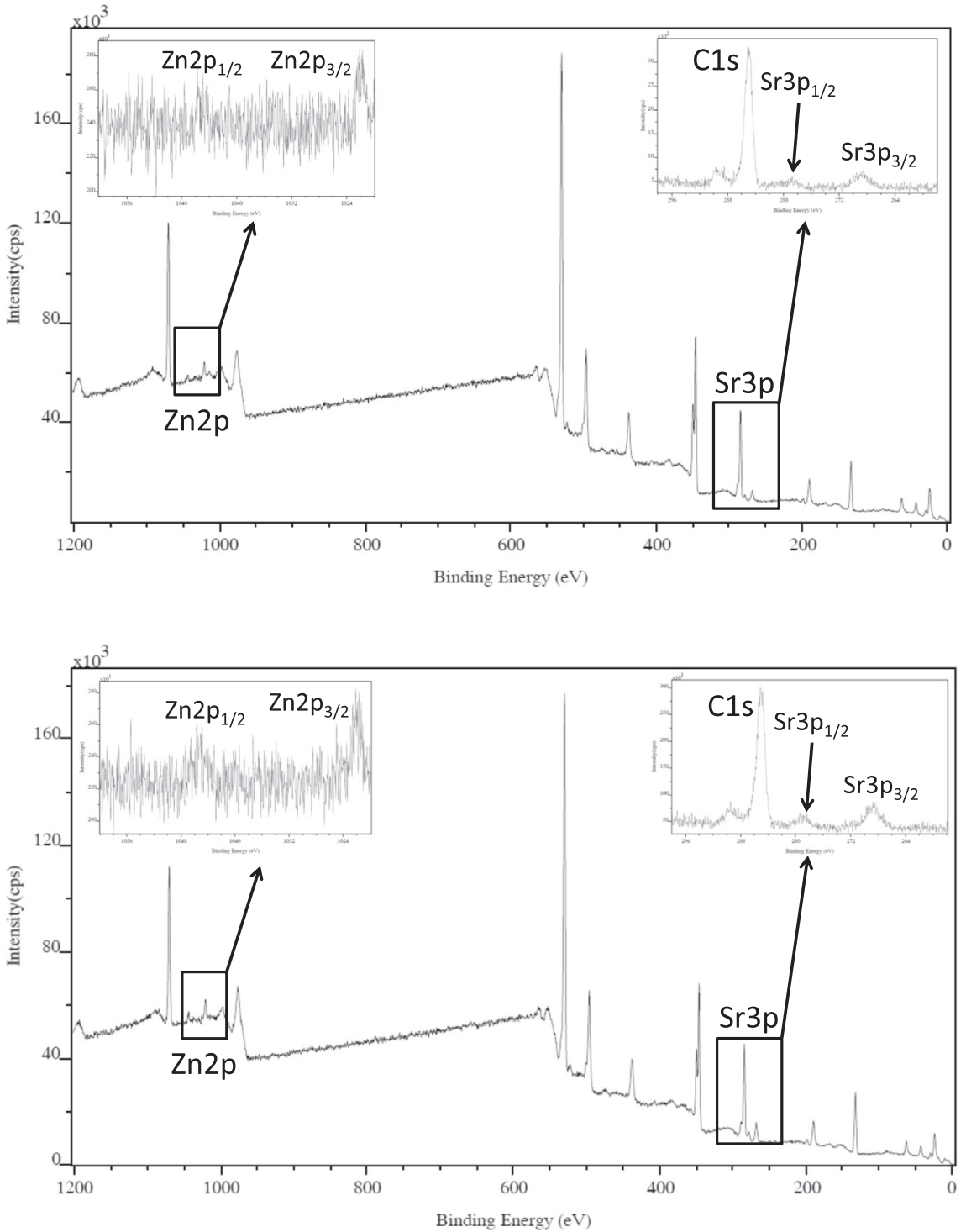

Fig. 5. XPS spectra for $\mathrm{Sr} / \mathrm{Zn} 5 \%$ nHA sample.

Fig. 6. XPS spectra for $\mathrm{Sr} / \mathrm{Zn} 10 \%$ nHA sample.
$3.09 \pm 0.75$, as reported in Table 5. The Sr/Zn-2.5\%nHA, Sr/Zn-5\%HA and $\mathrm{Sr} / \mathrm{Zn}-10 \%$ nHA samples all have nanocrystals, which are much smaller in size (both in length and breadth) than the nHA powder, as reported in Table 5, with typically lengths $<40 \mathrm{~nm}$ and breadths $<$ $11 \mathrm{~nm}$. The analysis of the TEM results, as highlighted in Fig. 8, show that there is a statistical difference in the length and breadth of the nHA, when compared with the co-substituted materials. In addition, within the co-substituted materials significant differences are observed in the length of the crystals between all samples. With respect to the aspect ratio, there was a significant difference between the nHA and the $\mathrm{Sr} / \mathrm{Zn}-5 \% \mathrm{HA}$ and $\mathrm{Sr} / \mathrm{Zn}-10 \%$ nHA samples (and between all of the different co-substituted materials). However, no significant statistical difference was observed in the aspect ratio between the nHA and the
$\mathrm{Sr} / \mathrm{Zn}-2.5 \%$ nHA sample.

\section{Discussion}

4.1. $X R D$

The XRD diffraction patterns for all 3 co-substituted samples, $\mathrm{Sr}$ / Zn2.5\%nHA, Sr/Zn5\%nHA and Sr/Zn10\%nHA in Fig. 1(b)-(d), show definite peak shifts to the left indicating that the diffraction peaks have shifted to slightly lower 2 theta $(2 \theta)$ values, in comparison to the nHA sample. This is due to $\mathrm{Sr}^{2+}$ ions with a larger ionic radius $(1.12 \breve{A})$ re-

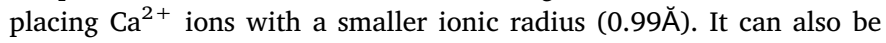
observed in the 002 peaks in Fig. 1 that as the wt $\%$ substitution of

Table 3

Comparative XPS ratios for standard nHA and substituted nHA powders ( \pm standard deviation).

\begin{tabular}{|c|c|c|c|c|c|c|c|}
\hline \multirow[t]{2}{*}{ Sample } & \multicolumn{7}{|l|}{ Ratios } \\
\hline & $\mathrm{Ca} / \mathrm{P}$ & $(\mathrm{Ca}+\mathrm{Sr}) / \mathbf{P}$ & $(\mathrm{Ca}+\mathrm{Zn}) / \mathbf{P}$ & $(\mathrm{Ca}+\mathrm{Sr}+\mathrm{Zn}) / \mathbf{P}$ & $\mathrm{Sr} /(\mathrm{Sr}+\mathrm{Ca})$ & $\mathrm{Zn} /(\mathrm{Zn}+\mathrm{Ca})$ & $\mathbf{S r}+\mathrm{Zn} /(\mathbf{S r}+\mathrm{Zn}+\mathrm{Ca})$ \\
\hline nHA & $1.61 \pm 0.04$ & - & - & - & - & - & - \\
\hline $\mathrm{Sr} / \mathrm{Zn}-2.5 \% \mathrm{nHA}$ & $1.53 \pm 0.06$ & $1.59 \pm 0.05$ & $1.56 \pm 0.06$ & $1.63 \pm 0.05$ & $0.04 \pm 0.01$ & $0.02 \pm 0.01$ & $0.06 \pm 0.01$ \\
\hline Sr/Zn-5\%nHA & $1.42 \pm 0.03$ & $1.50 \pm 0.04$ & $1.47 \pm 0.04$ & $1.54 \pm 0.05$ & $0.05 \pm 0.01$ & $0.03 \pm 0.01$ & $0.08 \pm 0.01$ \\
\hline $\mathrm{Sr} / \mathrm{Zn}-10 \% \mathrm{nHA}$ & $1.38 \pm 0.01$ & $1.55 \pm 0.01$ & $1.45 \pm 0.04$ & $1.63 \pm 0.04$ & $0.11 \pm 0.01$ & $0.05 \pm 0.01$ & $0.15 \pm 0.02$ \\
\hline
\end{tabular}


Table 4

XPS peak positions for standard HA and substituted HA powders.

\begin{tabular}{|c|c|c|c|c|c|c|c|c|}
\hline \multirow[t]{2}{*}{ Sample } & \multicolumn{8}{|c|}{ Peak positions - B.E. (eV) } \\
\hline & C1s & 01s & $\mathrm{Ca} 2 \mathrm{p}_{3 / 2}$ & P2p & P2s & Sr3p $p_{3 / 2}$ & $\mathrm{Zn} 2 \mathrm{p}_{3 / 2}$ & Na1s \\
\hline nHA & 285.0 & 531.6 & 347.2 & 133.7 & 190.9 & - & - & - \\
\hline Sr/Zn-2.5\%nHA & 285.0 & 530.5 & 346.5 & 132.8 & 190.0 & 268.3 & 1021.7 & 1071.0 \\
\hline Sr/Zn-5\%nHA & 285.0 & 530.7 & 346.5 & 132.7 & 190.0 & 268.7 & 1021.7 & 1071.3 \\
\hline $\mathrm{Sr} / \mathrm{Zn} 10 \%$ nHA & 285.0 & 531.0 & 347.0 & 133.0 & 190.3 & 268.8 & 1022.0 & 1071.5 \\
\hline
\end{tabular}

strontium increases, from Fig. 1(b)-(d), so does the level of shifting to the left and lower $2 \theta$ values increase, suggesting that gradually larger amounts of strontium have been successfully substituted into the nHA with each sample. The peaks also exhibited significant broadening with increasing $\mathrm{Sr}^{2+}$ content as can be seen in Fig. 1(b)-(d). Again, this result would be expected as increased $\mathrm{Sr}^{2+}$ substitution increases the strain within the lattice $[3,22,23]$. The XRD peak broadenings found in the 3 co-substituted samples may also indicate the successful substitution of $\mathrm{Zn}^{2+}$ ions for $\mathrm{Ca}^{2+}$ ions within the nHA lattice. However, peak positions would be expected to shift very slightly to higher $2 \theta$ values, indicating the substitution of the smaller $\mathrm{Zn}^{2+}$ ion for the $\mathrm{Ca}^{2+}$ ion within the HA crystal lattice, causing a shrinkage in unit cell parameters. A peak shift to the right and higher $2 \theta$ values cannot be observed in Fig. 1 but this could be due to the shift to the left and lower $2 \theta$ values caused by the $\mathrm{Sr}^{2+}$ substitution within the same samples, masking any subsequent peak shift to the right caused by substituted $\mathrm{Zn}^{2+}$ ions. Previous research substituting HA with zinc alone has produced XRD diffraction patterns with these noticeable peak shifts to the right and higher $2 \theta$ values, which could be used to confirm along with XPS data that $\mathrm{Zn}^{2+}$ ions have been successfully substituted within the nHA lattice however the larger amounts of $\mathrm{Sr}^{2+}$ ions substituted within the nHA lattice conceal any peak shift or increase in $2 \theta$ value associated with $\mathrm{Zn}^{2+}$ substitution $[10,24,25]$.

\subsection{FTIR}

The FTIR peak positions observed for the nHA material for the P-O stretching and O-P-O bending vibrations were similar to those previously known for $\mathrm{HA}$, as were those observed for the $\mathrm{O}-\mathrm{H}$ librational and stretching modes. No peaks indicative of $\mathrm{HPO}_{4}{ }^{2-}$ functional groups were detected for the nHA material (typically peaks for $\mathrm{HPO}_{4}{ }^{2-}$ are seen around 1120 and $580 \mathrm{~cm}^{-1}$ ) [17,19].

The 3 co-substituted samples appear to have broader P-O stretching bands located around 1099, 1043 and 964, and the O-P-O bending bands at 603 and 565, which could be due to both $\mathrm{Sr}^{2+}$ and $\mathrm{Zn}^{2+}$ substituting for calcium in the nHA lattices. There is also increased $\mathrm{CO}_{3}{ }^{2-}$ substitution, in all 3 co-substituted samples, which previous literature has highlighted as an expected outcome when $\mathrm{Zn}^{2+}$ substitutes for $\mathrm{Ca}^{2+}$ in the nHA lattice $[25,26]$. In addition to these results, O-H stretching bands located around $3570 \mathrm{~cm}^{-1}$ and $\mathrm{O}-\mathrm{H}$ librational bands around $632 \mathrm{~cm}^{-1}$ reduce in intensity for all 3 co-substituted samples in comparison to the nHA sample. This de-hydroxylation supports the fact that substitution of $\mathrm{Sr}^{2+}$ and $\mathrm{Zn}^{2+}$ ions for $\mathrm{Ca}^{2+}$ disrupts the nHA lattice.
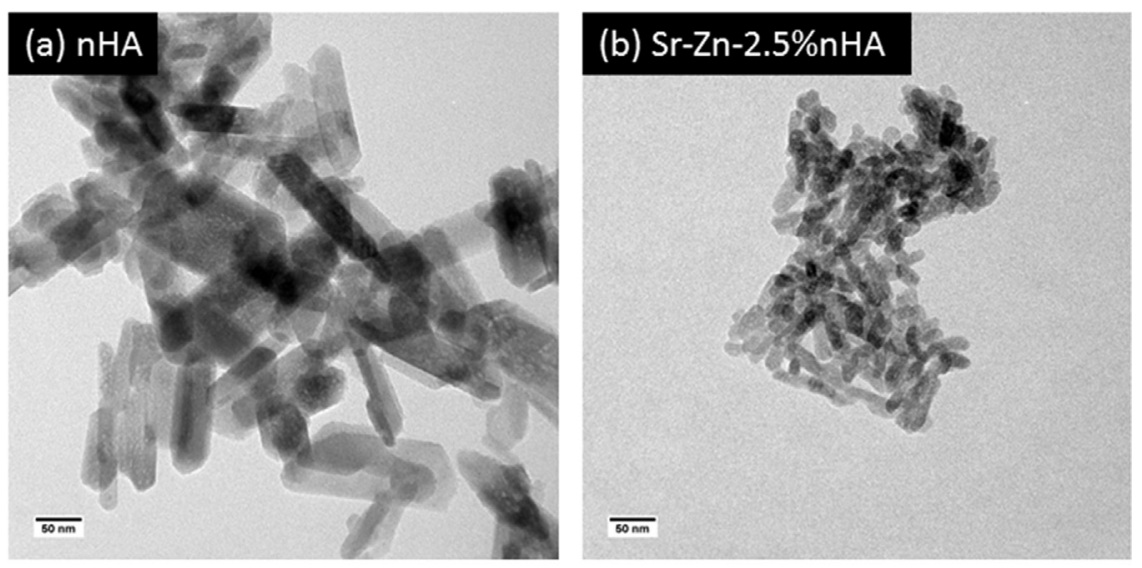

Fig. 7. TEM images of nHA and co-substituted nHA samples.
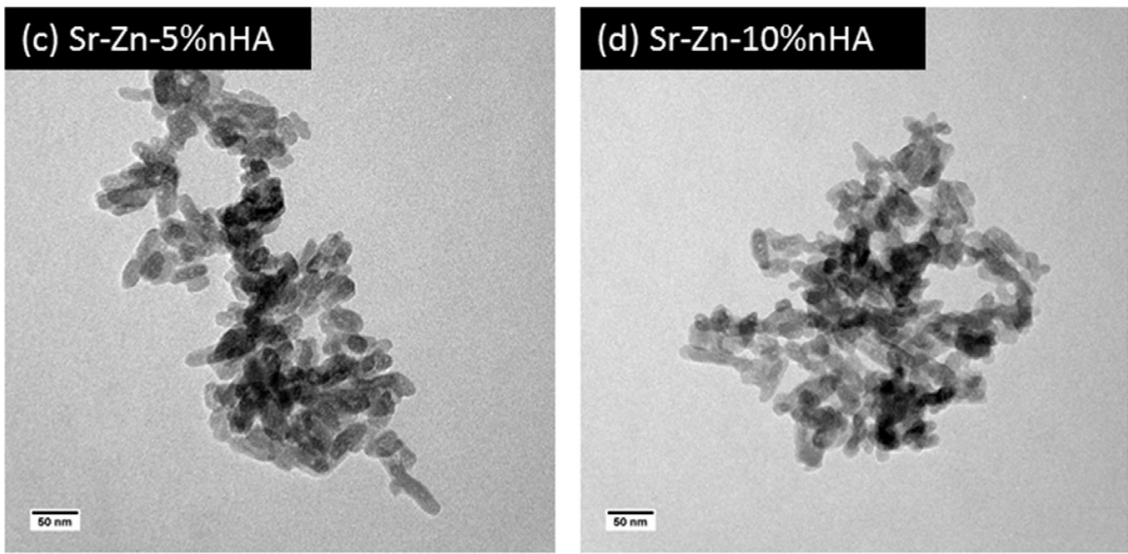
Table 5

Dimensions of nanocrystals ( \pm standard deviation) measured using TEM analysis and processed using ImageJ software.

\begin{tabular}{lllll}
\hline Sample & nHA & $\begin{array}{l}\text { Sr/Zn-2.5\%- } \\
\text { nHA }\end{array}$ & Sr/Zn-5\%-nHA & $\begin{array}{l}\text { Sr/Zn-10\%- } \\
\text { nHA }\end{array}$ \\
\hline $\begin{array}{c}\text { Length } \\
\text { (nm) }\end{array}$ & $99.5 \pm 12.9$ & $31.4 \pm 6.5$ & $23.0 \pm 3.0$ & $17.6 \pm 3.3$ \\
$\begin{array}{c}\text { Breadth } \\
\text { (nm) }\end{array}$ & $33.8 \pm 7.8$ & $9.5 \pm 1.5$ & $10.0 \pm 1.5$ & $10.2 \pm 1.4$ \\
Aspect ratio & $3.09 \pm 0.75$ & $3.40 \pm 0.96$ & $2.36 \pm 0.47$ & $1.75 \pm 0.33$
\end{tabular}

\subsection{XPS}

The $\mathrm{Ca} / \mathrm{P}$ ratio for the nHA sample was $1.61 \pm 0.04$, slightly lower than the expected 1.67 for stoichiometric HA. All 3 co-substituted samples had further reduced $\mathrm{Ca} / \mathrm{P}$ ratios, $1.53 \pm 0.06$ for $\mathrm{Sr} / \mathrm{Zn}-2.5 \%$ nHA, $1.42 \pm 0.03$ for $\mathrm{Sr} / \mathrm{Zn}-5 \%$ nHA and $1.38 \pm 0.01$ for $\mathrm{Sr} / \mathrm{Zn}-10 \%$ nHA. This reduction in calcium content for each co-substituted sample would suggest successful substitution of strontium and zinc for calcium within the co-substituted $\mathrm{nHA}$ lattices, also as the $\mathrm{wt} \%$ of strontium and zinc increases from $2.5 \%, 5 \%$ and $10 \%$, the $\mathrm{Ca} / \mathrm{P}$ ratio decreases, suggesting gradually more is substituted into the nHA, replacing calcium.

The $(\mathrm{Ca}+\mathrm{Sr}) / \mathrm{P}$ ratios for each co-substituted sample, found in Table 3 are as follows; $1.59 \pm 0.05$ for $\mathrm{Sr} / \mathrm{Zn}-2.5 \%$ nHA, $1.50 \pm 0.04$ for $\mathrm{Sr} / \mathrm{Zn}-5 \% \mathrm{nHA}$ and $1.55 \pm 0.01$ for $\mathrm{Sr} / \mathrm{Zn}-10 \%$ nHA. It can be seen that for each sample the ratio is larger for $(\mathrm{Ca}+\mathrm{Sr}) / \mathrm{P}$ in comparison to the $\mathrm{Ca} / \mathrm{P}$ ratios alone, providing further evidence that for each co-substituted sample strontium has been successfully substituted for calcium within the nHA lattice. Again, the $3(\mathrm{Ca}+\mathrm{Zn}) / \mathrm{P}$ ratios for the cosubstituted samples, Table 3 are as follows; $1.56 \pm 0.06$ for $\mathrm{Sr} / \mathrm{Zn}-2.5 \%$ nHA, $1.47 \pm 0.04$ for $\mathrm{Sr} / \mathrm{Zn}-5 \%$ nHA and $1.45 \pm 0.04$ for $\mathrm{Sr} / \mathrm{Zn}-10 \%$ nHA. This would again confirm that zinc has successfully substituted for calcium within the nHA lattice as all $3(\mathrm{Ca} / \mathrm{Zn}) / \mathrm{P}$ ratios are larger than the previous $\mathrm{Ca} / \mathrm{P}$ ratios for each corresponding co-substituted sample. This is again confirmed with the 3 co-substituted samples $(\mathrm{Ca}+\mathrm{Sr}+$ $\mathrm{Zn}) / \mathrm{P}$ ratios, found in Table 3 which are; $1.63 \pm 0.05$ for $\mathrm{Sr} / \mathrm{Zn}-2.5 \%$ nHA, $1.54 \pm 0.05$ for $\mathrm{Sr} / \mathrm{Zn}-5 \%$ nHA and $1.63 \pm 0.04$ for $\mathrm{Sr} / \mathrm{Zn}-10 \%$ $\mathrm{nHA}$, which are again larger figures than the previous $\mathrm{Ca} / \mathrm{P},(\mathrm{Ca}+\mathrm{Sr}) /$ $\mathrm{P}$ and $(\mathrm{Ca}+\mathrm{Zn}) / \mathrm{P}$ ratios for each individual sample, again confirming the successful substitution of both strontium and zinc for calcium within each nHA lattice.

$\mathrm{The} \mathrm{Sr} / \mathrm{Sr}+\mathrm{Ca})$ ratios found in Table 3 are interesting as they show a clear increase in strontium substitution for each increasing wt $\%$ sample, therefore, for $\mathrm{Sr} / \mathrm{Zn}-2.5 \% \mathrm{nHA}, 0.04 \pm 0.01$, for $\mathrm{Sr} / \mathrm{Zn}-5 \% \mathrm{nHA}$, $0.05 \pm 0.01$ and for $\mathrm{Sr} / \mathrm{Zn}-10 \% \mathrm{nHA}, 0.11 \pm 0.01$. This data indicates that as the wt $\%$ concentration of strontium is increased from $1.25 \%$ to
$2.5 \%$ to $5 \%$ for each co-substituted sample the subsequent percentage ratios of atomic concentration also increase accordingly, confirming that as a larger percentage concentration of strontium is added at the beginning of the reaction, a larger amount of strontium is substituted for calcium within the nHA lattice of each sample. A similar trend can be seen with the $\mathrm{Zn} /(\mathrm{Zn}+\mathrm{Ca})$ ratios again located in Table 3, a clear increase in zinc substitution for each increasing $w \mathrm{t} \%$ sample can be seen, for Sr/Zn-2.5\%nHA, $0.02 \pm 0.01$, for Sr/Zn-5\%nHA, $0.03 \pm 0.01$ and for $\mathrm{Sr} / \mathrm{Zn}-10 \% \mathrm{nHA}, 0.05 \pm 0.01$. This would again indicate that as the $w \mathrm{t} \%$ concentration of zinc is increased from $1.25 \%, 2.5 \%$ to $5 \%$ for each co-substituted sample the subsequent percentage ratios of atomic concentration also increase, again confirming that as a larger percentage concentration of zinc is added at the beginning of each synthesis, a larger amount of zinc is substituted for calcium within the nHA lattice of each sample. Again, the $\mathrm{Sr}+\mathrm{Zn} /(\mathrm{Sr}+\mathrm{Zn}+\mathrm{Ca})$ ratios for $\mathrm{Sr} / \mathrm{Zn}$ 2.5\%nHA, $0.06 \pm 0.01$, for $\mathrm{Sr} / \mathrm{Zn}-5 \%$ nHA, $0.08 \pm 0.01$ and for $\mathrm{Sr} / \mathrm{Zn}-$ $10 \%$ nHA, $0.15 \pm 0.02$ agree with the strontium and zinc ratios and show a distinct rise in \% atomic concentration, as the starting percentage concentrations of both strontium and zinc are increased. This indicates that a larger amount of both strontium and zinc has been cosubstituted into the nHA lattice of each sample, as the starting concentrations of strontium and zinc increase from $1.25 \%$ to $2.5 \%$ to $5 \%$ for each ion. This suggests that the wet precipitation synthesis successfully substitutes larger concentrations of both strontium and zinc within the nHA lattice as amounts of the starting strontium nitrate and zinc nitrate hexahydrate are increased.

Small amounts of sodium were also detected in the XPS spectra analyses, with the Na1s peak located between 1071.0 and $1071.5 \mathrm{eV}$ for all 3 co-substituted samples. This was caused by the use of sodium hydroxide as a buffer to increase the $\mathrm{pH}$ above 10 during each precipitation reaction and has been found to encourage the substitution of zinc for calcium within the nHA lattice. It should be noted that XPS is a surface analytical technique and only penetrates the uppermost surface $(1-10 \mu \mathrm{m})$ of each sample.

\subsection{TEM}

The TEM results show clearly that as the co-substituted $w \mathrm{t} \%$ of strontium and zinc increased from 2.5, 5 to $10 \%$, the average particle length for each sample reduced from $31.4 \pm 6.5 \mathrm{~nm}, 23.0 \pm 3.0 \mathrm{~nm}$ and $17.6 \pm 3.3 \mathrm{~nm}$, respectively with the breadth remaining relatively constant at $9.5 \pm 1.5 \mathrm{~nm}, 10.0 \pm 1.5 \mathrm{~nm}$ and $10.2 \pm 1.4 \mathrm{~nm}$, respectively. This corresponds with previous research which showed that nHA substituted with both strontium and zinc produced smaller sized particle samples $[27,28]$. It has also been reported in previous literature that as the concentration of the substituted ion rises, regardless of

\section{TEM Length (nm)}

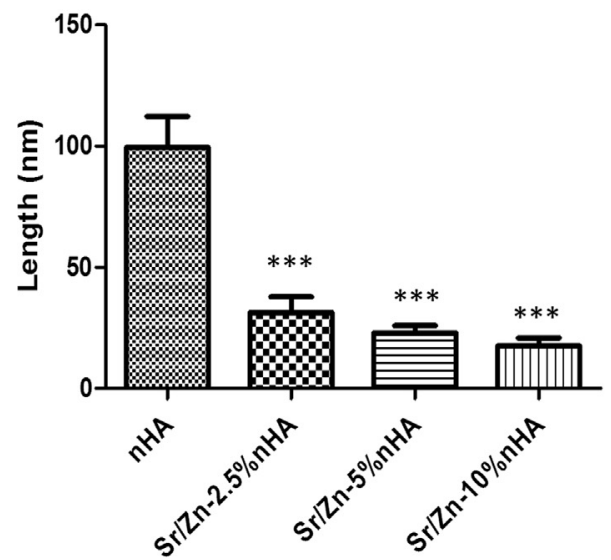

TEM Breadth (nm)

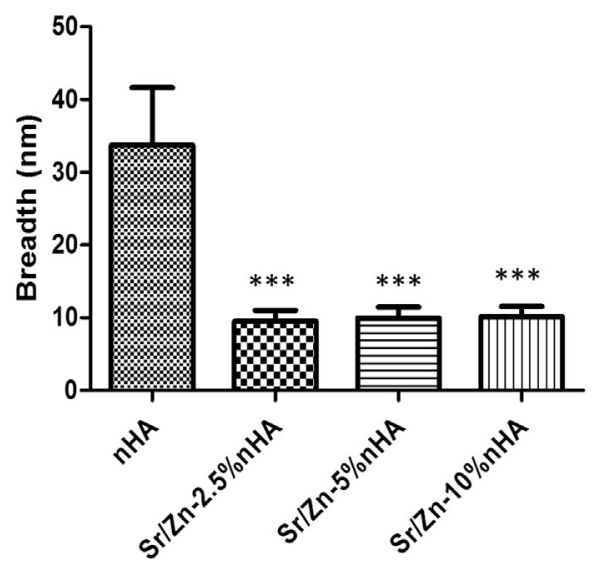

TEM Aspect Ratio

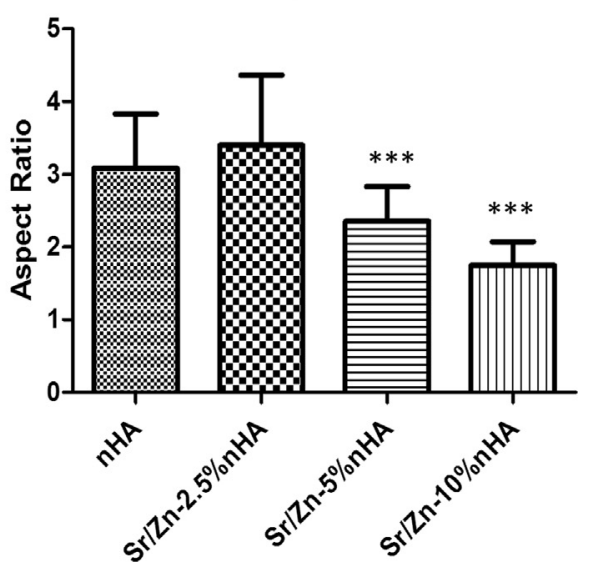

Fig. 8. TEM statistical comparisons between nHA and co-substituted $\mathrm{Sr} / \mathrm{Zn} \mathrm{nHA}$ samples. ${ }^{* * *}$ Statistically significant at $\mathrm{P}<.0001$ in comparison with the control nHA. 
whether it is strontium or zinc, the subsequent substituted nHA crystals tend to agglomerate [27,28]. The statistical analysis of the crystal length, breadth and aspect ratio here, highlight that as the concentration of the co-substituted ions increase, it has an obvious effect on the growth of the crystals, (with higher ion substitutions inhibiting crystal growth).

This study has also found that for every sample analysed using TEM, the observed nanocrystals appeared granular in nature, which may indicate a high level of porosity and an increased surface area within both the nHA and substituted nHA materials synthesised. An optimised surface nano-topography could in turn increase adsorption of specific proteins and ultimately improve osteoblast cell adhesion and promote osteoblast proliferation and differentiation [29]. Previous research has also found that nano-sized HA, with a larger surface area, has increased sinterability and densification which can in turn improve its mechanical properties and fracture toughness [2,29].

\section{Conclusion}

The specific aim of this work was to synthesise nHA and nHA cosubstituted with strontium and zinc at varying concentrations, Sr/Zn$2.5 \%$ nHA, $\mathrm{Sr} / \mathrm{Zn}-5 \% \mathrm{nHA}$ and $\mathrm{Sr} / \mathrm{Zn}-10 \% \mathrm{nHA}$, using an aqueous precipitation technique. The results indicated that nHA and nHA co-substituted with strontium and zinc were successfully produced at varying concentrations. The nHA materials produced did not contain any other $\mathrm{CaP}$ impurity phases and were proven to be nano-sized in scale, as shown by XRD, FTIR, XPS and TEM analyses. Further comparison did indicate that crystallinity did vary as the amount of $\mathrm{Sr}^{2+}$ and $\mathrm{Zn}^{2+}$ increased within the co-substituted samples, with the degree of structural order decreasing as $\mathrm{Ca}^{2+}$ ions were progressively replaced with either larger $\mathrm{Sr}^{2+}$ or smaller $\mathrm{Zn}^{2+}$ ions with increasing dehydroxylation observed within the co-substituted samples, which further highlighted disruption of the HA lattice. Also, the particle morphology of the cosubstituted nHA samples changed with increased co-substitution, with the particles steadily reducing in length.

Very few previous studies have investigated the synthesis of nHA materials co-substituted with $\mathrm{Sr}^{2+}$ and $\mathrm{Zn}^{2+}$. Therefore, the successful co-substitution of both strontium and zinc within nHA, as demonstrated successfully here, could provide a more bioactive bone substitute biomaterial. However, there is a need for further detailed in vitro and in vivo studies to confirm the efficacy of these co-substituted materials.

\section{Acknowledgements}

The authors would like to acknowledge the Ph.D. funding provided by the Department for the Economy (Northern Ireland) to support this work.

\section{References}

[1] K. Fox, P.A. Tran, N. Tran, Recent advances in research applications of nanophase hydroxyapatite, ChemPhysChem 13 (2012) 2495-2506, http://dx.doi.org/10. 1002/cphc. 201200080.

[2] H. Zhou, J. Lee, Nanoscale hydroxyapatite particles for bone tissue engineering, Acta Biomater. 7 (2011) 2769-2781, http://dx.doi.org/10.1016/j.actbio.2011.03 019.

[3] A. Siddharthan, S.K. Seshadri, T.S.S. Kumar, Rapid synthesis of calcium deficient hydroxyapatite nanoparticles by microwave irradiation, Trends Biomater. Artif. Organs 18 (2005) 110-113, http://dx.doi.org/10.1016/j.ssc.2004.02.045.

[4] I.R. de Lima, G.G. Alves, C.A. Soriano, A.P. Campaneli, T.H. Gasparoto, E. Schnaider Ramos, L.Á. de Sena, A.M. Rossi, J.M. Granjeiro, Understanding the impact of divalent cation substitution on hydroxyapatite: an in vitro multiparametric study on biocompatibility, J. Biomed. Mater. Res. Part A 98A (2011) 351-358, http://dx.doi. org/10.1002/jbm.a.33126.

[5] E. Bonnelye, A. Chabadel, F. Saltel, P. Jurdic, Dual effect of strontium ranelate: stimulation of osteoblast differentiation and inhibition of osteoclast formation and resorption in vitro, Bone 42 (2008) 129-138, http://dx.doi.org/10.1016/j.bone. 2007.08.043.

[6] M. Roy, G.A. Fielding, A. Bandyopadhyay, S. Bose, Effects of zinc and strontium substitution in tricalcium phosphate on osteoclast differentiation and resorption,
Biomater. Sci. (2013) 74-82, http://dx.doi.org/10.1039/c2bm00012a.

[7] D.V. Shepherd, K. Kauppinen, R.A. Brooks, S.M. Best, An in vitro study into the effect of zinc substituted hydroxyapatite on osteoclast number and activity, J. Biomed. Mater. Res. - Part A 102 (2014) 4136-4141, http://dx.doi.org/10.1002/ jbm.a.35089.

[8] J.H. Shepherd, D.V. Shepherd, S.M. Best, Substituted hydroxyapatites for bone repair, J. Mater. Sci. Mater. Med. 23 (2012) 2335-2347, http://dx.doi.org/10.1007/ s10856-012-4598-2.

[9] V. Aina, L. Bergandi, G. Lusvardi, G. Malavasi, F.E. Imrie, I.R. Gibson, G. Cerrato, D. Ghigo, Sr-containing hydroxyapatite: morphologies of HA crystals and bioactivity on osteoblast cells, Mater. Sci. Eng. C 33 (2013) 1132-1142, http://dx.doi. org/10.1016/j.msec. 2012.12.005.

[10] N. Lowry, Y. Han, B.J. Meenan, A.R. Boyd, Strontium and zinc co-substituted nanophase hydroxyapatite, Ceram. Int. 43 (2017) 12070-12078, http://dx.doi.org/ 10.1016/j.ceramint.2017.06.062.

[11] L. Robinson, K. Salma-Ancane, L. Stipniece, B.J. Meenan, A.R. Boyd, The deposition of strontium and zinc Co-substituted hydroxyapatite coatings, J. Mater. Sci. Mater. Med. 28 (2017), http://dx.doi.org/10.1007/s10856-017-5846-2.

[12] L. Tortet, J.R. Gavarri, G. Nihoul, Study of Protonic Mobility in CaHPO4.2H2O (Brushite) and CaHPO4 (Monetite) By Infrared Spectroscopy and Neutron Scattering, 16, 1997, pp. 6-16.

[13] A.R. Boyd, C. O'Kane, B.J. Meenan, Control of calcium phosphate thin film stoichiometry using multi-target sputter deposition, Surf. Coat. Technol. 233 (2013) 131-139, http://dx.doi.org/10.1016/j.surfcoat.2013.04.017.

[14] C.-J. Chung, H.-Y. Long, Systematic strontium substitution in hydroxyapatite coatings on titanium via micro-arc treatment and their osteoblast/osteoclast responses, Acta Biomater. 7 (2011) 4081-4087, http://dx.doi.org/10.1016/j.actbio. 2011.07.004.

[15] A.R. Boyd, B.J. Meenan, N.S. Leyland, Surface characterisation of the evolving nature of radio frequency (RF) magnetron sputter deposited calcium phosphate thin films after exposure to physiological solution, Surf. Coat. Technol. 200 (2006) 6002-6013, http://dx.doi.org/10.1016/j.surfcoat.2005.09.032.

[16] I.R. Gibson, W. Bonfield, Novel synthesis and characterization of an AB-type carbonate-substituted hydroxyapatite, J. Biomed. Mater. Res. 59 (2002) 697-708, http://dx.doi.org/10.1002/jbm.10044.

[17] A.R. Boyd, L. Rutledge, L.D. Randolph, B.J. Meenan, Strontium-substituted hydroxyapatite coatings deposited via a co-deposition sputter technique, Mater. Sci. Eng. C 46 (2015) 290-300, http://dx.doi.org/10.1016/j.msec. 2014.10.046.

[18] A. Costescu, I. Pasuk, F. Ungureanu, A. Dinischiotu, F. Huneau, S. Galaup, P.L.E. Coustumer, D. Predoi, C. Ftir, Physico-Chemical Properties of Nano-Sized Hexagonal Hydroxyapatite Powder Synthesized by Sol-Gel, 5, 2010, pp. 89-1000.

[19] A.R. Boyd, L. Rutledge, L.D. Randolph, I. Mutreja, B.J. Meenan, The deposition of strontium-substituted hydroxyapatite coatings, J. Mater. Sci. Mater. Med. 26 (2015) 65, http://dx.doi.org/10.1007/s10856-014-5377-z.

[20] W. Xia, C. Lindahl, C. Persson, P. Thomsen, J. Lausmaa, H. Engqvist, Changes of Surface Composition and Morphology after Incorporation of Ions into Biomimetic Apatite Coatings, 2010, 2010, pp. 7-16. 〈https://dx.doi.org/10.4236/jbnb.2010. 11002>.

[21] Y. Zhao, D. Guo, S. Hou, H. Zhong, J. Yan, C. Zhang, Y. Zhou, Porous Allograft Bone Scaffolds: Doping with Strontium, 8, 2013, pp. 1-10. 〈https://dx.doi.org/10.1371 journal.pone.0069339>.

[22] Y.Y. Özbek, F.E. Baştan, F. Üstel, Synthesis and characterization of strontium-doped hydroxyapatite for biomedical applications, J. Therm. Anal. Calorim. 125 (2016) 745-750, http://dx.doi.org/10.1007/s10973-016-5607-3.

[23] L. Li, X. Lu, Y. Meng, C.M. Weyant, Comparison study of biomimetic strontiumdoped calcium phosphate coatings by electrochemical deposition and air plasma spray: morphology, composition and bioactive performance, J. Mater. Sci. Mater. Med. 23 (2012) 2359-2368, http://dx.doi.org/10.1007/s10856-012-4633-3.

[24] A. Anwar, S. Akbar, A. Sadiqa, M. Kazmi, Novel continuous flow synthesis, characterization and antibacterial studies of nanoscale zinc substituted hydroxyapatite bioceramics, Inorg. Chim. Acta 453 (2016) 16-22, http://dx.doi.org/10.1016/j.ica. 2016.07.041.

[25] I. Pereiro, C. Rodriguez-Valencia, C. Serr, C. Solla, J. Serra, P. Gonzalez, Structural properties of ZnO films grown by picosecond pulsed-laser deposition, Appl. Surf Sci. 258 (2012) 9192-9197.

[26] M. Kavitha, R. Subramanian, R. Narayanan, V. Udhayabanu, Solution combustion synthesis and characterization of strontium substituted hydroxyapatite nanocrystals, Powder Technol. 253 (2014) 129-137, http://dx.doi.org/10.1016/j.powtec 2013.10.045.

[27] V. Krishnan, A. Bhatia, H. Varma, Development, characterization and comparison of two strontium doped nano hydroxyapatite molecules for enamel repair / regeneration, Dent. Mater. 32 (2016) 646-659, http://dx.doi.org/10.1016/j.dental. 2016.02.002

[28] K.P. Tank, P. Sharma, D.K. Kanchan, M.J. Joshi, FTIR, Powder XRD, TEM and Dielectric Studies of Pure and Zinc Doped Nano-Hydroxyapatite, 1316, 2011, pp. 1309-1316. 〈https://dx.doi.org/10.1002/crat.201100080〉.

[29] S.V. Dorozhkin, Nanosized and nanocrystalline calcium orthophosphates, Acta Biomater. 6 (2010) 715-734, http://dx.doi.org/10.1016/j.actbio.2009.10.031.

[30] H. Zreiqat, Y. Ramaswamy, C. Wu, A. Paschalidis, Z. Lu, B. James, O. Birke, M. McDonald, D. Little, C.R. Dunstan, The incorporation of strontium and zinc into a calcium-silicon ceramic for bone tissue engineering, Biomaterials 31 (2010) 3175-3184, http://dx.doi.org/10.1016/j.biomaterials.2010.01.024.

[31] V. Mourino, J.P. Cattalini, A.R. Boccaccini, Metallic ions as therapeutic agents in tissue engineering scaffolds: an overview of their biological applications and strategies for new developments, J. R. Soc. Interface 9 (2012) 401-419, http://dx.doi. org/10.1098/rsif.2011.0611. 
[32] F. Yang, D. Yang, J. Tu, Q. Zheng, L. Cai, L. Wang, Strontium enhances osteogenic differentiation of mesenchymal stem cells and in vivo bone formation by activating Wnt/catenin signaling, Stem Cells (2011), http://dx.doi.org/10.1002/stem.646.

[33] T. Kubota, T. Michigami, K. Ozono, Wnt signaling in bone metabolism, J. Bone Miner. Metab. 27 (2009) 265-271, http://dx.doi.org/10.1007/s00774-009-0064-8.

[34] M. Arioka, F. Takahashi-Yanaga, M. Sasaki, T. Yoshihara, S. Morimoto, M. Hirata Y. Mori, T. Sasaguri, Acceleration of bone regeneration by local application of lithium: Wnt signal-mediated osteoblastogenesis and Wnt signal-independent suppression of osteoclastogenesis, Biochem. Pharmacol. 90 (2014) 397-405, http://dx. doi.org/10.1016/j.bcp.2014.06.011.

[35] S.C. Cox, P. Jamshidi, L.M. Grover, K.K. Mallick, Preparation and characterisation of nanophase $\mathrm{Sr}, \mathrm{Mg}$, and $\mathrm{Zn}$ substituted hydroxyapatite by aqueous precipitation, Mater. Sci. Eng. C 35 (2014) 106-114, http://dx.doi.org/10.1016/j.msec. 2013.10. 015.

[36] F. Ren, R. Xin, X. Ge, Y. Leng, Characterization and structural analysis of zincsubstituted hydroxyapatites, Acta Biomater. 5 (2009) 3141-3149, http://dx.doi. org/10.1016/j.actbio.2009.04.014.

[37] H. Storrie, S.I. Stupp, Cellular Response to Zinc-Containing Organoapatite: An In Vitro Study of Proliferation, Alkaline Phosphatase Activity and Biomineralization, 26, 2005, pp. 5492-5499. 〈https://dx.doi.org/10.1016/j.biomaterials.2005.01. 043>.

[38] G.S. Kumar, A. Thamizhavel, Y. Yokogawa, S.N. Kalkura, E.K. Girija, Synthesis, characterization and in vitro studies of zinc and carbonate co-substituted nanohydroxyapatite for biomedical applications, Mater. Chem. Phys. 134 (2012) 1127-1135, http://dx.doi.org/10.1016/j.matchemphys.2012.04.005.

[39] R.J. Friederichs, H.F. Chappell, D.V. Shepherd, S.M. Best, Synthesis, characterization and modelling of zinc and silicate co-substituted hydroxyapatite, J. R. Soc. Interface 12 (2015) 20150190, http://dx.doi.org/10.1098/rsif.2015.0190.

[40] L. Stipniece, K. Salma-Ancane, N. Borodajenko, M. Sokolova, D. Jakovlevs, L. Berzina-Cimdina, Characterization of Mg-substituted hydroxyapatite synthesized by wet chemical method, Ceram. Int. 40 (2014) 3261-3267, http://dx.doi.org/10. 1016/j.ceramint.2013.09.110.

[41] M. Vandrovcova, T.E.L. Douglas, W. Mróz, O. Musial, D. Schaubroeck, B. Budner R. Syroka, P. Dubruel, L. Bacakova, Pulsed laser deposition of magnesium-doped calcium phosphate coatings on porous polycaprolactone scaffolds produced by rapid prototyping, Mater. Lett. 148 (2015) 178-183, http://dx.doi.org/10.1016/j matlet.2015.02.074.

[42] K. Salma-Ancane, L. Stipniece, A. Putnins, L. Berzina-Cimdina, Development of Mgcontaining porous $\beta$-tricalcium phosphate scaffolds for bone repair, Ceram. Int. 41 (2015) 4996-5004, http://dx.doi.org/10.1016/j.ceramint.2014.12.065.

[43] G.A. Fielding, M. Roy, A. Bandyopadhyay, S. Bose, Antibacterial and biologica characteristics of silver containing and strontium doped plasma sprayed hydroxyapatite coatings, Acta Biomater. 8 (2012) 3144-3152, http://dx.doi.org/10. 1016/j.actbio.2012.04.004.

[44] A. Zamani, G.R. Omrani, M.M. Nasab, Lithium's effect on bone mineral density, Bone 44 (2009) 331-334, http://dx.doi.org/10.1016/j.bone.2008.10.001.

[45] H.D. Jang, J.H. Shin, D.R. Park, J.H. Hong, K. Yoon, R. Ko, C.Y. Ko, H.S. Kim, D. Jeong, N. Kim, S.Y. Lee, Inactivation of glycogen synthase kinase-3?? Is required for osteoclast differentiation, J. Biol. Chem. 286 (2011) 39043-39050, http://dx. doi.org/10.1074/jbc.M111.256768.

[46] J. Albers, J. Keller, A. Baranowsky, F.T. Beil, P. Catala-Lehnen, J. Schulze, M. Amling, T. Schinke, Canonical Wnt signaling inhibits osteoclastogenesis independent of osteoprotegerin, J. Cell Biol. 200 (2013) 537-549, http://dx.doi.org/ 10.1083/jcb.201207142.

[47] W. Wei, D. Zeve, J.M. Suh, X. Wang, Y. Du, J.E. Zerwekh, P.C. Dechow, J.M. Graff, Y. Wan, Biphasic and dosage-dependent regulation of osteoclastogenesis by -catenin, Mol. Cell. Biol. 31 (2011) 4706-4719, http://dx.doi.org/10.1128/MCB. 05980-11.

[48] V. Stanic, S. Dimitrijevic, J. Antic-Stankovic, M. Mitric, B. Jokic, I.B. Plecac, S. Raicevic, Synthesis, characterization and antimicrobial activity of copper and zinc-doped hydroxyapatite nanopowders, Appl. Surf. Sci. 256 (2010) 6083-6089, http://dx.doi.org/10.1016/j.apsusc.2010.03.124.

[49] W.-L. Du, Y.-L. Xu, Z.-R. Xu, C.-L. Fan, Preparation, characterization and antibacterial properties against E. coli $\mathrm{K}(88)$ of chitosan nanoparticle loaded copper ions, Nanotechnology 19 (2008) 85707, http://dx.doi.org/10.1088/0957-4484/ 19/8/085707.

[50] R.J. Friederichs, R.A. Brooks, M. Ueda, S.M. Best, In vitro osteoclast formation and resorption of silicon-substituted hydroxyapatite ceramics, J. Biomed. Mater. Res. Part A 103 (2015) 3312-3322, http://dx.doi.org/10.1002/jbm.a.35470.

[51] D.M. Reffitt, N. Ogston, R. Jugdaohsingh, H.F.J. Cheung, B.A.J. Evans, R.P.H. Thompson, J.J. Powell, G.N. Hampson, Orthosilicic Acid Stimulates Collagen Type 1 Synthesis and Osteoblastic Differentiation in Human Osteoblast-Like Cells In Vitro, 32, 2003, pp. 127-135. 〈https://dx.doi.org/10.1016/S8756-3282(02) 00950-X>.

[52] R. Ferro De Godoy, S. Hutchens, C. Campion, G. Blunn, Silicate-substituted calcium phosphate with enhanced strut porosity stimulates osteogenic differentiation of human mesenchymal stem cells, J. Mater. Sci. Mater. Med. 26 (2015) 5387, http:// dx.doi.org/10.1007/s10856-015-5387-5.

[53] J.C. Merry, I.R. Gibson, S.M. Best, W. Bonfield, Synthesis and characterization of carbonate hydroxyapatite, J. Mater. Sci. Mater. Med. 9 (1998) 779-783, http://dx. doi.org/10.1023/A:1008975507498.

[54] V. Stanic, S. Dimitrijevic, D.G. Antonovic, B.M. Jokic, S.P. Zec, S.T. Tanaskovic, S. Raicevicc, Synthesis of fluorine substituted hydroxyapatite nanopowders and application of the central composite design for determination of its antimicrobial effects, Appl. Surf. Sci. 290 (2014) 346-352, http://dx.doi.org/10.1016/j.apsusc 2013.11.081. 